\title{
Global desirings and translocal loves: transgendering and same-sex sexualities in the southern Philippines $^{1}$
}

\section{Mark Johnson}

Traditionally, anthropologists have contributed to debates on gender and sexuality by indicating that such-and-such a society values and valorizes the practice of same-sex sexuality in altogether different ways than other societies, including the anthropologists' own.(1) At best, such scholarship helps disrupt the universalization of the binary distinction between homosexuality and heterosexuality and the categorical oppositions of the feminine and masculine. At worst it is a kind of "butterfly collecting," to borrow Leach's phrase (1971), in which classification is a principal objective. Forms of same-sex sexualities have been classified into types or categories, such as mixed and transgendered, age or transgenerational and egalitarian homosexuality (for example, Greenberg 1988). As Kath Weston notes, "Many of the scholars working within lesbian and gay studies in anthropology find themselves engaged in a form of ethnocartography, looking for evidence of samesex sexuality and gender ambiguity in 'other' cultures" (1993:340-341). Anthropologists are yet to come to terms with the shifting historical contexts and spatial fields out of which such categories and practices have emerged, not sui generis, but as the specific products of political and cultural entanglements (Thomas 1997). In this article I seek to extend Weston's call for a dynamic contextual and transactional approach to gender and sexual diversity-by foregrounding thetranslocal character and content of nonmainstream identities and identifications. I describe a situation in the southern Philippines where a range of same-sex sexual encounters exists, from strictly commoditized transactions to gifting relations, each of which has significant implications for the way in which the partners are gendered. The meanings attached to these encounters are importantly shaped by the various real and imagined worlds with which they are associated and within which they are set. My main argument is that gender and sexuality are neither static nor singular. Rather, they are dynamic processes that unfold in-even as they create and reproduce-multidimensional sexual, cultural, and social geographies. These might be called local ethnosexual cartographies, to reappropriate Weston's term (1993).

I begin with an introduction to my terminology and its theoretical import. I use the term local (as in local ethnosexual cartographies) to signal neither a worldview nor cultural units discretely bounded in space and time. Rather, local denotes contested fields of social signification in an increasingly "global ethnoscape" (Appadurai 1991). Local implies a recognition of the movement of people and ideas across boundaries. It is precisely this translocal dimension of contemporary social life that makes descriptive taxonomies so problematic, necessitating reformulation of cultural particularity (the old anthropological trump card) in matters of gender and sexual diversity. As others have argued, treating various formulations of gender and sexuality as isolated, self-perpetuating islands of desire and desirability is neither theoretically sound nor empirically valid.(2)

In this article I focus on the way in which accounts of same-sexual relations in the southern Philippines are variously framed in terms of ethnicity, gender, and sexual comportment. I show how these terms and relationships are, in turn, shaped by same-sexual encounters and experiences that extend beyond this particular locale, as is evident in the accounts given by transgenderedly identified gay men of their experiences as the paid sexual partners of foreign men while living and working abroad. Although the majority of gays have never traveled or worked abroad, the stories of those who have-and the gossip about them and their experiencesbecome a constitutive part of the way in which gay identities are formulated locally.

\footnotetext{
${ }^{1}$ This is an Accepted Manuscript of an article published by Wiley in American Ethnologist on 07 January 2008, available online: https://anthrosource.onlinelibrary.wiley.com/doi/abs/10.1525/ae.1998.25.4.695
} 
Indeed, translocality is as much about fantasy and imagination, a traversing of conceptual spaces, as it is about the actual movement of goods or people (Rapport and Dawson 1998). On location: local meanings of gay gender and sexuality

This article is based on ethnographic research on transgendering and homosexuality among the mainly Muslim Tausug communities of the southern Philippines, particularly in the town of Jolo on the island of Sulu. I also worked among Sama there. The Island of Sulu (Lupa' Sug) is the major population center for the Muslim Tausug. Together with Islam itself, Sulu is a primary point of symbolic identification, occupying a central place in local cultural geographies. Jolo was also the site of some of the fiercest fighting between armed Muslim separatists and Philippine government forces in the 1970s. To the south is Sabah, Malaysia, an important destination for illegal immigrant workers known as "TNT" (tago-nang-tago). This group includes transvestite homosexuals. Sabah is part of the greater Malay Muslim region with which local Tausug and Sama sometimes identify themselves. To the north is Zamboanga; though it has a sizeable Muslim population, Zamboanga is more generally seen locally as the gateway to the rest of the Philippines, conceptualized along ethnic-religious lines as the world of the Bisaya'. This term is used in opposition to Muslim to refer to any Christian Filipinos, wherever they may be from in the Philippines and whatever may be their Christian sect.

Beyond regional boundaries lies the rest of the world, the world abroad, as local people frequently refer to it. The world abroad consists of primarily two cultural "others." Both are associated with important destinations for Tausug and Sama who work overseas as contract labor. These are the world of Islam and the Middle East to the West, and the world of the Milikan (the local transliteration of American, although in fact it is often used to reference any white foreign other), which conceptually lies to the east. Each - the Christian Philippines, Malaysia, the Middle East, and America-carries a symbolic load in the ongoing struggle over local identities and identifications. More important, for the purposes of this article, each is associated by gays with different kinds of sexual experiences and social transactions, a fact that is nowhere more apparent than in conventions within which homosexuality and transgendering are locally understood.

As if drawn straight out of a textbook on transsexualism, the most common response I received to the question, "what does it mean to be gay?" was that being gay meant having a women's heart stuck inside a man's body. Illustrative of the entanglement of local concepts with global images and discourses, this reply also signals the specifically transgendered idiom within which gay identity in the southern Philippines is framed. Like "women," the object (krush) of gay sexual desire is said, both by gays and others, to be men, not women or other gays. Put another way, gays say that "like women" they desire to be penetrated or "worked" by a "real man": they distinguish between "real men" and gays by their respective positions as penetrating and penetrated partner in sexual intercourse, as is the case with the distinction between active and passivo (or inserter and insertee) in the sexual conventions of Latin America and the Mediterranean (Murray 1992:xxii).(4)

Although sex between two gays, or anal penetration of a boyfriend and call boy (male prostitute) by a gay, is certainly not unknown (see discussion below), most of the gays I spoke to said that it is rare. In regard to two gays having sex, most found the idea repulsive. In the local swardspeak (gay argot) these are termed pong-piyang or incestuous gays, and most gays quickly respond, "Ay! Subay sunugun! They should be burned." Similarly, gays frequently said that to penetrate one's boyfriend was like making him a woman. A contestant at a gay beauty contest voiced the widely held distaste (among gays) for such behavior. The master of ceremonies asked "her," "If you found out your boyfriend was also gay, would you keep him as your boyfriend?" The contestant responded, "No, because I don't want to eat my own ass!" Moreover, the idea of sex between two "real" men is seen by gays as even more disgusting. For a man to have sex with a gay in no way diminishes his status as 
a real man, so long as he is the inserting partner. However, if a man approaches another man or a gay and asks to be penetrated, he is said to be a silahis (double blade).

A silahis is a person who has demonstrated his capability to penetrate like a man, but who also desires to be penetrated. It is the silahis, in fact, who-in terms of the sexual protocols at leastblurs the common distinction between masculine and feminine sexuality. In contrast to the term gay, the term silahis is not used openly in self-reference or in reference to another person. Rather, similar to the way in which the term kinaidos (fucked man) was employed in ancient Greece (cf. Winkler 1990), silahis is used only in the context of making defamatory statements, or calling into question another man's masculinity. The term gay does not signal a gendered sexual identity that is any more secure or unproblematicthan the designation silahis. In fact, the local term bantut (impotent, effeminate, transvestite), which is the term most frequently used by nongays to refer to gays, implies both penile impotency and its corollary; a transgressive and voracious sexuality: in local Islamic theology, anal intercourse is understood as an inversion and defilement of the most sacred of passageways, a woman's vagina. Thus, while young Tausug-Muslim men talk about being fellated or masturbated by the bantut, they almost universally deny and express strong aversion to anal intercourse. Significantly, Tausug men say the bantut engage in intercourse with the Bisaya' or Christian Filipino. The engenderment and valorization of the bantut and the sexuality associated with them constitutes a sexual cartography closely informed by the particular history of ethnic conflict and political violence in the region (cf. Johnson 1995a).

Briefly, non gay individuals often trace what they perceive to be an increase in the number of the bantut back to the beginning of martial law in the 1970s when fighting between the Moro National Liberation Front (MNLF) and government forces was at its height. Explanations given for the increase inthe number of bantut at that time included Christian Filipino cultural influence and fear on the part of some young men who lost their courage in the face of the violent abuses of the "Christian" military. For the Tausug, the defining characteristics of masculinity are courage and bravery. Thus, in mainstream representations, the bantut are gendered as both sexually and ethnically deviant. My interest here, however, is less with the way gays symbolically mediate the effects of the Muslim community's forced assimilation into the Christian Philippine state than with the way gays -in part through the very appropriation of the term gay-negotiate their own identity within a wider configuration of symbolic violence and social exclusion (exclusion marked by the term bantut). In particular, the term gay is part of an attempt to construct an identity, gendered feminine and defined primarily in terms of an imagined America. While often defined in terms of an imagined America (and by idioms and images drawn from or associated with America), the appropriation of the term gay and the identification with an imagined gay universe signals gays' own transgendered projects. Those projects are informed less by contemporary Western homosocialities than by local sensibilities about love, kinship, gender, and gifting relations. These are sensibilities that, as I outline in the following sections, clearly emerge in the stories gays tell about their various relationships, both real and imagined, with men.

Before proceeding, it is important to say something here about my own identifications in this field of variously gendered persons and sexualities. I was identified by local people as an American and by gays as a masculine-identified man and a potential lover. References to America might have been structured around the possibility of romance with me. Certainly it was expected that I would conform to certain ideas about American style-for example, that I would smoke only American cigarettes, such as Marlboro, and wear only American-made clothing, including Rayban sunglasses. Similarly, gays expected that I would both conform to and in some ways transcend the pattern of behavior of local men in their relationship with gays. They believed, for example, that in exchange for sharing their stories with me, I would have sex with them, and I would identify with their desire for reciprocal ties of care and compassion in a way that local men would not or could not. 
America looms large both in gay and popular discourse, and it was clear that as a key cultural symbol, gay concern with America transcended my own case. The fact that I did not conform to their expectations did not diminish their association of America with beauty and style. Neither did my faltering attempts to convey to local gays some sense of gay struggles and identities in Britain and North America, structured around the homosexual and heterosexual distinction, alter their perceptions of America as a place where true-love relations might exist between feminine-identified gays and "real" (that is to say, masculine-identified) men. I do not mean to suggest that my presence as a masculine-identified American had no bearing or significance on these stories. Rather, my presence was significant precisely because, like America itself, it provided the kind of space for formulating views of their loves and lives which are otherwise excluded from the dominant view that regards them as sexually rapacious and deviant.

\section{Call, service, and ha! ha! boys: men working gays}

I begin with gay accounts of call-boy or service-boy relationships. These are short-term sexual relationships in which men are paid by gays to work them, that is, to masturbate ("play the piano"), fellate ("sing"), or penetrate them in anal intercourse ("dance"). Call boys are primarily associated with Zamboanga and other larger cities such as Cebu and Manila (cf. Whitam 1992 and Mathews 1990 for a description of call-boys' activities in each of these places respectively). 5 Most gays from the town of Jolo visit Zamboanga to pick up call boys. There is a fairly welldeveloped call-boy circuit there, although unlike the situation for female prostitutes, call boys are not run by pimps but through informal networks of contacts and well-known pick-up spots. In Jolo there seems to be fewer call boys.

There are several important things that emerge in gay representations of these relations. The first concerns exchange. Gays see the call-boy relationship as a balanced sex-for-money exchange. A second issue concerns the gender identities proffered in these exchanges. People who openly identify themselves as gay (or who are identified as bantut) are, at least in Zamboanga and Sulu, never paid by masculine-identified men for sex. Rather, it is men who are paid for sex by gays. All the call boys I knew considered themselves to be men; however, gays, as well as other men, often regarded the call boys with ambivalence, sometimes supporting their identity as men, but sometimes expressing the view that they might be secret "closet queens" or, even worse, silahis, since they were commonly known to perform sexual acts (especially fellatio) associated with gays. Similarly, although most gays upheld the local protocols of gay sexuality in their statements, denying that they would pay to penetrate a call boy, they often suggested that they had friends or knew other gays who had done so. For these reasons, call-boy relationships are the most ambiguous in terms of the gender identities proffered in sexual exchange.

The evidence summarized in this section suggests that there may be a wider range of same-sexual practices than is represented in the local protocols. More important, the evidence highlights the wider context within which a distinctly engendered gay sexuality has been formulated, a key part of which is the ethnic-religious identifications of the respective partners. Both Muslim Tausug and Christian gays in the town of Jolo say that the sexual services of more mature youths or call boys are only available in larger urban and predominately Bisaya' (Christian Filipino) areas. Confirming what nongays told me, they insisted that no Muslim Tausug man would ever accept money to perform sexual services for gays, although they might be paid to receive sexual services from gays. 6

\section{Working abroad: bennie boys in Sabah.}

The opposite of the call-boy situation is the case of gays who have been to Sabah and worked as transvestite-homosexual prostitutes (bennie or billyboys). The circuit of migrants for prostitution forms part of the more general movement of people and goods between Malaysia and the southern Philippines. According to one gay who had recently returned from Malaysia, transvestite- 
homosexual prostitutes can earn an average of 100 Ringgit (Malay Currency) a night, which in 199192 was about 1,000 Pesos, approximately ten times a good day's earnings in a beauty parlor in Jolo (one of the major occupations of gays in Sulu). One older gay who had gone to Borneo in the late 1960s related the following story of her stay in Sandakan: (7)

I stayed a long time in Borneo. I was still very young then. [Just over 20 years ago in the late 1960s.] Four of us gays fled there. When we arrived there, we didn't yet know how to speak Malayu [the national language of Malaysia]. We had just arrived. So we put on our makeup on the boat, and we asked the man, "Is it all right if we go into town with skirts on?"

The people on the boat said, "Oi! You are sure to be caught by the police and you have only just arrived." I said, "No we won't. "So off we went in our skirts-I had a very short miniskirt with halter and shoulder bag. After that the police saw us and they were just wondering what was up with us. They called to us, but we couldn't understand what they were saying. They brought us to an Englishman, whose eyes were blue.

So I said, "Here we are-Mercy, Helen, Gloria, Naida." The Englishman asked me, "Are you a bennie boy?" I said, "Yes, I am a bennie boy. Why? Can you afford?" I then told Nadia who knew how to speak English much better than me. "Talk to the man in English." The man said, "What do you want?" So I said, "Answer him Naida." The Englishman said, "What?" I said "What?" Then he said, "Do you know how to dance?" I said, "Yes.' So he put on a tape, and we started doing the twist, the dance from before, until we were all sweating. So then they fed us bread and gave us 7-Up.

"You are beautiful," one of them said. "Follow me," he said, "I want to ask you something." I said, "Where?" but he made me follow him. Then he started kissing me on the neck. I said, "I am not prepared. There will be a time." Meaning, I'll come back to you another time. I hadn't cleaned and was afraid, but he told me not to worry about it. So he penetrated me, but just a little bit. Then he gave me an envelope. When I opened it, I saw that it was two ten Ringgit notes. Whether American, Japanese, Chinese it was all the same, all of them gave me money, 20 dollars. It was the same whether it was oral or anal. So that's why back here in Jolo I will not give boys money when they ask me for it [after having sex with them].

Helen's story illustrates a number of points in respect to the way gay relationships with foreign men are represented by gays. Helen makes it clear that it is gays who are the object of foreign men's desire. No sooner had she and her friends arrived in Malaysia than an English man chatted them up. This is in direct contrast to the situation in the southern Philippines where, in both gay and mainstream discourse, it is men who are said to be the object of gay desire. While in the Philippines gays pay men for sex, in Malaysia men pay gays for sex. Helen sometimes referred to her work and status in Sabah as prostitution, as did one other gay who had previously worked in Malaysia. They referred to their relationships with men abroad, in general, as short term, sex-for-cash exchanges. In contrast to call-boy relationships, however, there seemed to be no ambiguity with respect to gendered sexual conventions. Moreover, there were other relationships that these and other gays had with foreign men (both locally and abroad) that were not short term, sex-for-money exchanges. Helen, for instance, lived with a man as a maid and mistress for six months in Sabah. Similarly, I knew two other gays who had spent several years working in Saudi Arabia. Both of them claimed to have had Arab lovers. In sum, foreign men were seen to be both willing to pay for the sexual services of feminine identified gays from the Philippines and also to be inclined affectively toward them.(8) It is important to reiterate, however, that only a few of the gays I knew had lived or traveled abroad. Nevertheless, the stories of those who had importantly shape the way gays talk about their lives and loves more generally. 


\section{The kursinada scenario}

Thus far I have concentrated mainly on accounts of commoditized same-sex relations. In order to appreciate fully the extent to which narratives of other places inform gay identifications, it is important to explain in more detail the full range of gay relationships with men. In both gay and mainstream discourse, gay-men relations are most often talked about, in terms of what I have called the kursinada scenario (following local parlance).

In contrast to the terms call boy and bennie boy, the term kursinada does not mark a certain category or type of relationship. Rather, kursinada might best be heard as indicating a specific intentionality or trajectory of desire. The use of the English word target by local people in association with the term kursinada emphasizes the sense of kursinada as the active pursuit of a desired end, be it an object, person, or response. To be someone's kursinada, in other words, is to be the object of that person's desire. Gay or bantut desire is said to be marked by lavish gifts to men. In gays' and men's narratives, an implicit connection is often drawn between gays' desire for men (expressed in terms of kursinada) and men's desire for the gifts gays give to them (these gifts, too, are referred to in terms of kursinada). This link between sexuality and commodities is not entirely fortuitous since the gays (and bantut) are said to be masters of style and appropriate imitation (cf. Johnson 1996, 1997).

While the basic transactional element of the kursinada scenario is generally the same in gays' and men's representations, significant differences emerge between them with respect to the intentionalities in these transactions. Men often represent the bantut as easy money (hikasin), always ready and willing to pay men to engage in sexual play. Older married men explain what they see as the contrary behavior of younger men hanging around the many gay-transvestite beauty parlors in town as a way of having a free drinking spree, obtaining spending money, or acquiring desired material possessions. Young men do not deny the sexual pleasure they receive at the hands of the bantut, but stress that they never actively reciprocate the bantut, either materially or sexually, particularly in anal intercourse. In short, men present themselves as tricksters capable of successfully playing off the vanity, petty jealousies, and potentially dangerous sexual appetites of the bantut in order both to enhance their own masculinity and to turn a profit.

Working for love: gays on casual, steady, and live-in relationships What men represent to be the voracious sexual appetite of the bantut in the kursinada scenario obviously masks what is a much more complex set of intentionalities in gay representations. Although kursinada may refer to a temporary sexual liaison, kursinada is often expressed in terms of a true love or steady relationship involving romantic attachments. Casual relationships are associated with younger gays in their late teens or early twenties. In addition, casuals, as they are called by gays, reflect the more pragmatic stance of older gays resigned to their own inability to realize true love relations. As in the kursinada scenario described by men, some gays describe sexual encounters as "work"; gays fellate or masturbate the men and are left to masturbate on their own.

Other gays told me that when they engage in casual sex, they insist on mutual masturbation. Although gay representations of casual sexuality valorize the transgenderedly defined sense of being like women (expressed among otherthings in their desire to be penetrated anally), they also valorize sexual reciprocity as the basis for a good time, which they also desire. This is illustrated by the discussions I had with Jamey and Isma, two gays in their late teens, about the boys with whom they have casual relations.

MJ: Do you masturbate by yourself or do you just masturbate them? Jamey: Of course, so you are satisfied. Sometimes I masturbate them and they masturbate me. 
Isma: If you have had contact with a boy and you do not come, it hurts, so we masturbate. Or if we find another boy then we have them masturbate us.

MJ: So the boys play with you when you are having sex?

Jamey: Yes, sometimes. It depends on their style, so long as they have their [my emphasis] pleasure, but afterwards that's all there is.

MJ: Do you ever have sex with other gays?

Jamey: No, but if I am with a boy who is not my type, then I have them work me, masturbate me. But if I am with someone I like, then I want them to penetrate me. With sex it should be reciprocal. If I masturbate them, they should masturbate me. I won't go along if all they want is for me to masturbate them.

In order to appreciate this insistence on sexual reciprocity, it is important to see it in light of what gays refer to as steady relationships. While younger gays are associated with casual relationships, it is primarily older gays and gays who have a regular income who are associated with steady relationships. This is because, in contrast to what is seen as the purely sexual one night stand of callboy and casual relationships, steady relationships are said to require much more in the way of material and emotional investment. This is also part of what is sometimes seen as marking the transition into becoming a real gay, a move from the flirtatious relations of high school into the more mature relations, associated primarily with later high school and college.

In gay representations of these relationships, gays depict men as involved in initiating and maintaining the relationship. What is intended, moreover, is not simply balanced sexual reciprocity as in casual relationships, but sharing and mutual understanding, the give and take of an emotional partnership.9 It is this desire for, and investment in, what are regarded to be true-love relationships that informs the intentionalities gays express in terms of the kursinada scenario.

In gay representations, steady or true-love relationships are also the ones most clearly articulated in terms of cross-gender identification and which most completely match the protocols oi gay sexuality. That is to say, mutual sexual gratification is seen as part of the ideal of the give and take of steady relationships: gays working their boyfriends in oral sex and, in turn, being worked by their boyfriends in anal intercourse. As one gay put it, "What makes us a woman is how we treat our boyfriend." He added that a steady is "someone who cares for global desirings and translocal loves 701 you and who will treat you like a real woman." Live-in relationships, in which a gay and man set up a household together, are rarely reported by gays, but they nonetheless represent the apex of possible gay-men relationships in the sense of affirming a man's true affection as well as a gay's feminine identity. It is precisely on the point of men's affection, however, that gays express the greatest disillusionment. While gays talk about their boyfriend's love for them and the give and take of their steady relationships, they would also say just as frequently that what boys-even their steadies-were really after was just money.

Evelyn: I have a steady right now. A Notre Dame high school boy. He is very tall. 17 years old. On Saturday and Sunday he sleeps at my place because I am the only one in the house. I do have a maid, but at night she goes home. The boy is really in love with me, so that when I tell him we will not be together anymore, he cries.

MJ: Do you support this boy?

Evelyn: Of course. I also give [money] to him, but he has more money and belongs to a wealthy family. Mostly here in Jolo the teenagers they use the gays. These days they use the gays. They are practical. When they need money, then they come around. That's the way it is. It's different from other places. The boys here are like call boys now. 
The one-sidedness of gay-men relationships is even more poignant in Evelyn's case since in local conventions men are expected to be the provisioned in amorous relations with women, and even more importantly, the generosity of the wealthy toward those who are less well off is understood as a mark of affection. Indeed, Evelyn's story was somewhat unique among those I collected inasmuch as most of the youths with whom gays had relations were from relatively poor families. Evelyn's response was to cast her boyfriend and other youths as call boys, thus reclaiming agency in a relationship in which she clearly felt she was being used. In contrast to call-boy and casual relationships, though, gays in steady relationships claim to support their kursinada financially and to work (fellate or masturbate) the men, while frequently being left to masturbate on their own.

\section{Love, American style}

It is important to understand steady and live-in relations primarily as idealized or imagined relations, since gay-men relationships, at least in this part of the Philippines, appear to be fleeting and ephemeral. Most gays talked about loves, steadies, and live-ins either in terms of now bygone relationships or, as was also often the case, as something that was possible only somewhere else. Indeed gays were rarely able to actualize such relationships in practice. Moreover, the language gays used to talk about love is, in large measure, drawn from an imagined notion of American love. Gay usage of the English word love, for instance, resonates with what Jean-Paul Dumont (1992) has written about the discourse of love in Siquior in the Visayas in the central Philippines. Dumont argues that, for townspeople, the use of the English word love signals a performative appropriation of America: an attempted transcendence of their own rural-proletarian roots, informed among other things by "comic book representations, Playboy-like imagery, and melodramatic radio renditions, not to mention all sorts of standard characterizations in love songs" (1992:195-1976). (To these I would add television and the cinema.) At the same time, love may also be used to signal the deviant and the derisive-for instance the love of hospitality girls and adulterous affairs, set against the traditional local ideal of gugma. Gugma, Dumont suggests, is an equally idealized construct describing "the agent that [binds] individuals to each other within actual families, parents to children and vice versa, siblings together, and spouses together" (1992:197).

In Jolo, the two local terms that are translated into the English word love are kasi and lasa.10 As I understand it, kasi refers to a specific active-affective emotion-a passion that cannot but help be expressed. Sexual expression is often explicit in kasi, as in the construct anak kasi (love child or child of an illicit union), lasa has a different connotation associated with the sentiments and reciprocal obligations of compassion and pity (ulung and luuy). In a way similar to gugma, the compound term kasi-lasa affirms a continuing affective orientation expressed as compassion and concern. The ideal of kasi-lasa is held up as the ideal of parent-child relations as well as wider community relations. It is the ideal implicit in the traditional notion of lindu' iban ramdam (love and desire) which refers to a man and woman who are said to pass into a sanctioned and blissful marital relation. Specifically, it marks the encompassment of passion within the domain of compassion and pity, which is symbolically indicated by a gifting relation, between a man and his kindred and a woman and her kindred. In contrast, the anak kasi (the child of passion) is a bastard child (halam birayat), that is, an ungifted child.

Although the English term love may imply both kasi and lasa, popular usage of the English term usually refers to unbridled passion, desire, and attraction. Love in this sense is often associated with the term romanca (romance) that references both Tagalog and English films and love stories, and which, as often as not, is associated with the illicit, even scandalous. For example, people I knew contrasted the American istyle (style) of love and marriage (in which everyone is said to do their own thing) with adat (local traditions) of love and marriage centered around the reciprocal obligations of usba and waris (respective kindred of the bride and groom). 
In terms of gay discourse, the performative aspect of romanca emerges as one part of their overall appropriation of beauty and style, as seen for instance in an older gay's story about how she became known as Helen of Troy:

Afterwards, well I remember when I started to be called Helen. I was 15 years old. There was this real handsome boy, a basketball player. Now what attracts people to me is my body, and I would wear underwear that came up past my hips, so that my boyfriend said, "It is good to have sex with you. It's just like a woman." But what was wanting was that he had a very small part. This was before I was called Helen of Troy. He asked me what my name was. I said, "Abdulhallim." He said, "Let's go to the movies. I will call you Helen of Troy." I asked, "Is this Helen of Troy beautiful?" "Oh yes. She is the most beautiful in the United States." Roseanna Protesta was the actress. So I said, "Lets go." So we went to the movie. Oh my! She was so beautiful, and there were many who fought over her. So what did I do? For the first time in my life, I kissed him, lips to lips because the movie was a romanca. So we kissed, and we even used our tongues, and I had never tried that before. We kept on kissing until the end of the movie, and the people started clapping and said, "They're kissing in the movie and they're kissing outside." When I opened my eyes, all the people were on their feet and they were looking at us. I thought they were clapping for the movie, but they were actually looking at us because I was lips to lips with the boy. So they said, "You will be baptized Helen of Troy." So until today I am known as Helen of Troy.

As this story illustrates, the term romanca is associated with the erotic in gay imagination. But while romanca is clearly part of gay discourse on love, what gays mean by true love also makes love an idealized binding agent. Moreover, in an inversion of the popular imaginings and usage, it is America and American love, which are most often associated by gays with the give and take of true love and steady relationships. In their imagination America (and American love) represent the most likely space for the realization of the mutually encompassing relations associated with the traditional idealized reciprocal obligations of care and compassion between marital partners and groups idealized in local traditions. This may be seen in the following excerpts from one gay life history in which free-love, America, and gay marriage are juxtaposed to and sometimes layered over appeals to common humanity and care.

MJ: Are you the one that provides for your kursinada or do they also provide for you? J: Frankly speaking, I am just gay. Even women are abandoned by men. Even hostesses [female prostitutes] are tricked by men. What more a gay? But I hope someday, somehow I can find a boy, who even if I pay him, will return good things to me. Not money. You can find money if you want. / am sensitive, very sensitive and I easily get hurt, but with boys that can't be avoided. They lie. Even husbands and wives lies to each other. I accept that. Even when they are married, if the husband is employed then his wife will give him money. That's like us. If you know him, he has no work, no money. He has just completed high school. No global desirlngs and $t$ ran si oca I loves 703 work. Self supporting. You feel care and compassion for them. I want them to know me as a person, you know, a human being with thoughts and blood. I am a human being. But sometimes boys, or even other gays, they look down on me. But I keep my chin up. When I look at myself in the mirror, if I look decent, then I hope that people will look at me decently. When they come up to the house as a person, then I invite them in as a person, but if they come up like an animal, then I treat them as an animal. We are the same, human beings. I am not proud. I just want to feel that I am treated like a person. Cays are taken for granted. I am just a woman in love, who they eat [devour?]. Mostly with men, you rarely meet someone who is liberated. You understand, you are from America, a place of free love.

MJ: What do kursinada want? Sex and money only? 
J: It depends. Some want beer, party, drugs. They don't give of themselves heartily, but just because of the money. They are interested in gays only because they want to drink. They don't do it heartily, just do because of money. There are some boys who, because of money, pretend to care for you. You care for them, and they like you because of your care for them. You have to care for them. In return there is also some concern, some inward debt, some desire [expressed on their part] even if it is just a little. It's not exactly love, but pity because you do everything. If they are older, then they also start to think things over. Most probably among the Tausug, if you know Islam, bantut is haram (unlawful). Muslim, conservative, at the same time, it is bad if bantut and men. There are no gays being married to men. Not as husband and wife but as friends there are. I think I read in a magazine that a gay and a boy got married in a church in America. I don't know, but they were pronounced as friends, not as husband and wife. I'm not sure what part of America this was, but they got married with a marriage contract. That's nice, to have a life like that. Are there [sex] transplants now? Maybe, have you ever interviewed gays in Manila? In U.S. you go stay five-six months. Of course the States, but you have to have the money.

A veritable poetic love collage, the above passage exemplifies the varied symbolic dimensions within, through, and against which local gay identities are formulated and experienced. Rather than single out J's story for extended commentary here, though, I want to develop some of its partial connections with other narrative accounts of gay-men relations and to suggest a conceptual framework within which the differences between true and false love and the local Muslim world and America, for example, might be usefully considered. Each individual gay's story reflects a highly subjective experience, yet it is only by mapping out the larger transactional and symbolic relations between the stories that anthropologists can begin to understand the meaning of various gay intentionalities.

\section{Between debts and remembrances: the structure of gay pathos}

The two primary axes along which gay-men relations might be mapped correspond to two local transactional schemes: debts (utang) and remembrances (panumtuman). Utang, commonly translated as debt or indebtedness, was defined by Mary Hollensteiner (1972:66) as a type of contractual or balanced reciprocity; however, while this definition highlights the ideological intent of utang, it elides both the historical reformulations and moral ambiguities that characterize presentday relations of indebtedness. For instance, utang is often linked straightforwardly to various forms of commodity exchange and wage labor. Profit often accrues asymmetrically in wage labor and entrepreneurial enterprises; more often, where utang takes the form of credit relations (such as in the padjak, the pawnshop), it is said to violate the local axiom, di' makapaganak in sin (money cannot [should not] bear children). This axiom is not just a local reformulation of the general Islamic prohibition against usury (gandariba), but also a specific assertion of the power of wealth and money as socially and intrinsically unreproductive.

In contrast, remembrances (the local gloss for the Tausug term panumtuman) refers to neither material exchange nor social reproduction alone, but to the production of social memory. In short, utang (indebtedness) signals exchange directed toward the realization of material profit or return (untung), while remembrancing signals a form of social transaction directed toward the realization of reciprocally constituted or shared inner selves. (Remembrancing is my term to indicate the sense of remembrances as ongoing activity rather than a passive state of being.) A person's status (that is, one's place in social memory) is not contained within the space of economic indebtedness, but is realized only through remembrancing relations. Thus, remembrances and debts might best be conceived as potentially encompassing and hierarchical rather than oppositional. This is the starting point for understanding the connections between exchange forms, gender status, and sexuality in gay-men relations, which I summarize in schematic form in Figure 1.(11) 


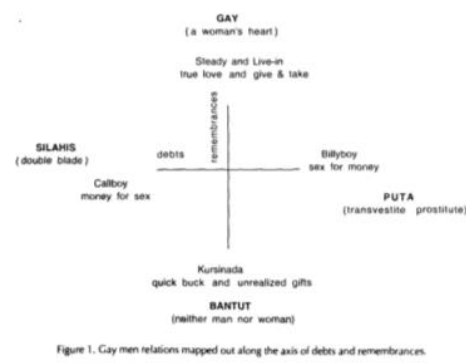

Although never explicitly articulated as such, call-boy relations fit within utang or debt exchange, inasmuch as they are commonly regarded by gays as participants in straightforward commodity transactions in which men are paid money for sex. Gays working in Sabah, Malaysia as bennie boys represent the inverse of this relation: men pay money for sex with gays. The discourse of true love, mutual understanding, and the give and take of idealized steady and live-in relations is in direct contrast to the commoditized exchange of call- and bennie-boy relations. The contrast between these two modes of exchange is even more explicit when gays talk about their inability to realize true love relations. As J (whose life history I excerpted above) says, "I hope someday, somehow, I can find a boy, who even if I pay him, will return good things to me. Not money. You can find money if you want." The sting for gays is that they are completely excluded from such remembrancing relations, at least by men. To put this another way, their gifts are not recognized as such but are continually translated and subverted through their commoditization by men.

Onto these axes of gift and commodity one can also map the gender implications for gays of each of these transactional forms. On the one hand, as I have noted, call boys are perhaps the most ambiguous in terms of the local sexual protocols. That is to say, both call-boy and gay gender identities are, like the exchange form through which they are negotiated, subject to ambiguity (gays become like men, call boys become like female prostitutes or silahis, double blades) since the sexual positions of the respective partners (as defined by the local protocols) are potentially inverted in these relationships.

Call-boy relationships are thus defined primarily in terms of sexual pleasure and not in terms of being or becoming like women. Gays commented on these relations by saying, "Grabi!" or "Grabi tuud," interjections that in this context indicated the intensity of the sexual desire and lust (biasan) that would lead them to engage in such liaisons. Again, as J put it, "If I am on top, I feel like I am paying only for the sake of sex, but when I am on the bottom it feels really good. When they are on the bottom, it's like they are just a hostess [a female prostitute). If you're really in love with them then you should be the one to do the work [masturbate and fellate them]."

On the other hand, steady and live-in relations are represented to be the relations within which gays most fully realize or accomplish their transgendered identifications, both sexually and otherwise. The link between a distinctly engendered sexuality and remembrancing was explicitly made by one gay who told me that his boyfriend had the night before penetrated him and left a remembrance (his semen) inside of him. Put negatively, however, men's duplicity and trickery is related by the gays to the fact that they are "not accepted by men as girls," and that it is always "in the end" that men leave gays for "real women," get married, and have children (children who are also said to be panumtuman umbul satu, "one's greatest remembrance").

Thus, gays are denied not only a reciprocally recognized identity such as lovers or wives would have, but also the reciprocal compassion and obligations said to characterize parent-child relationships. This is at the heart of gay pathos. Not having any remembrances or not being 
remembered is a matter of great concern and regret for gays (see also Mathews 1990:57).

From the map of gay relationships along the axis of local transactional schemes, I now turn to the important and interesting map of the particular worlds, imaginary and real, with which these schemas are associated. To anticipate: relationships abroad affirm gays' expressed transgendered projects while relationships at home deny and subvert these projects, as summarized in Figure 2.

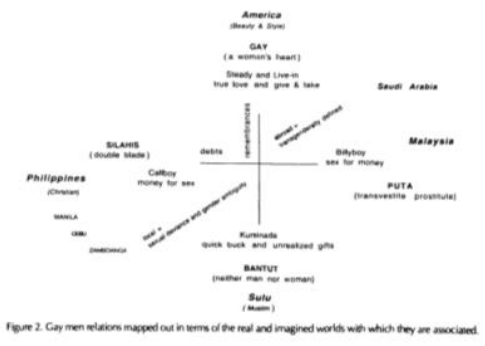

The associations gays draw between place, gender, and transaction are both specific and explicit, Jolo is associated with the duplicity and trickery of local Muslim Tausug and Sama men, the continual subversion of gay gifts, and the circumscription of gay transgendered identity in terms of the bantut, that is, as impotent men and unrealized or defiled women. Note, for instance, J's (who is himself a Muslim) comments (above) on local Muslim Tausugs, who regard gay-men relationships as haram (unlawful). Zamboanga, Cebu, and Manila (and by extension Christian Filipino men), on the other hand, while regarded by local gays as being freer in termsof homosexual contact, are regarded with all the gender ambiguity that attaches to the term silahis (double blade)-both by virtue oi their potential sexualities and transactional forms.

Manila, for instance, is commonly identified by the gays as a place where provincial gays risk being taken unaware by so-called pong-piyang or incestuous gays. Gay-men relations in Sabah, Malaysia, or Saudi Arabia, on the other hand, while similarly constructed in terms of call-boy transactional forms (at least in gay representations), retain a clear distinction between masculineidentified and feminine-identified sexual acts. This distinction marks them as the transgendered or female partner. While such relations may be constructed by gays as a variant of female prostitution, gays perceive a potential for the conversion of such relationships into true love and remembrancing relations. Thus, while they see local relationships as denying and subverting their transgendered projects, gays say their relationships abroad affirm them.

The associations gays draw between place, gender, and transaction are both specific and explicit, Jolo is associated with the duplicity and trickery of local Muslim Tausug and Sama men, the continual subversion of gay gifts, and the circumscription of gay transgendered identity in terms of the bantut, that is, as impotent men and unrealized or defiled women. Note, for instance, J's (who is himself a Muslim) comments (above) on local Muslim Tausugs, who regard gay-men relationships as haram (unlawful). Zamboanga, Cebu, and Manila (and by extension Christian Filipino men), on the other hand, while regarded by local gays as being freer in terms of homosexual contact, are regarded with all the gender ambiguity that attaches to the term silahis (double blade) - both by virtue of their potential sexualities and transactional forms. Manila, for instance, is commonly identified by the gays as a place where provincial gays risk being taken unaware by so-called pong-piyang or incestuous gays.

Gay-men relations in Sabah, Malaysia, or Saudi Arabia, on the other hand, while similarly constructed in terms of call-boy transactional forms (at least in gay representations), retain a clear distinction between masculine-identified and feminine-identified sexual acts. This distinction marks them as the transgendered or female partner. While such relations may be constructed by gays as a 
variant of female prostitution, gays perceive a potential for the conversion of such relationships into true love and remembrancing relations. Thus, while they see local relationships as denying and subverting their transgendered projects, gays say their relationships abroad affirm them.

Similarly, it is not simply gays who talk about remembrancing relations, or rather, their lack of them. Local, nongays often said that one of the tragic things about the gay and bantut was that they had no remembrances. As I have suggested elsewhere (Johnson 1995b), following Thomas (1991) and Rafael (1988), it is important to understand the various transactional trajectories of gifts and commodities, debts and remembrances-among other things-as strategies for the containment and appropriation of cultural otherness.(12) Denying gay or bantut remembrances and circumscribing them in the sphere of commodity exchange, I argue, is more than another way of referencing their sexual status. It is also a way of marking their exclusion from the transactions through which social memories (remembrances) are produced.

It would be a mistake, however, to see gays simply as tragic and powerless figures. As one of my gay informants told me about gay-men relationships at the very outset of my fieldwork, "Men think they are fooling gays, but gays know they are being fooled." While men present themselves as able to manipulate gays at will, my gay friends repeatedly told me that they choose their would-be lovers. Gays acknowledged their own ability to act as skilled manipulators of young men-for instance, flattering their good looks, making comments about the probable size of their penis, and so forthand echoing Evelyn's statement (above) about local lads becoming call boys: they insisted that "a good man can always be bought." As one gay told me about his current relationships,

I can say that I am wise enough. Because I know that guys took an advantage, and they can just get, get and get from you. And, for me I am wise now. Like that, I don't give to them, if I also do not get something from them in return. If I give them some clothes or if they ask me for some clothes, [I say] "Ok, I'll give you these clothes but you have to give me a fair exchange for them" [Gantihan mu isab]. "Or if I give you some money, then you have to have sex with me." I am alert to giving money. Because, I now know, in and out, the life of a gay. I can say that I am too educated in terms of that. I have experienced much having a relationship with a guy. I also take advantage of them. Wise, yah, I am wise now. Or when I don't have any boyfriends here, I contact the guy, just to feed my human wants, my desire. I give them what they want.

Many gays are able to negotiate their pleasure through the superior economic position they enjoy. In addition, the power that gays experience over men is due, at least in part, to the fact that gays are seen to embody and possess the same quality of otherness as the commodities-everything from Marlboro cigarettes to Addidas sportswear-that men say they are after in these relationships. Gays, who sometimes refer to their powers of seduction and self transformation in terms of "exposing my beauty" (cf. Cannell 1991:365), are positioned paradoxically between the alluring potency of an image of beauty and style defined in terms of America and local struggles over identity.

Conclusion: global desirings and translocal loves

In an article that explores the changing forms of homosexuality and the internationalization of gay identities, Dennis Altman suggests that scholars have generally faced a choice between "political economy, which argues for universalizing trends, and anthropology, which argues for cultural specificities" (1996:87). In my view, this is precisely the one choice anthropologists cannot afford to make. While in this article I have concerned myself with the particular articulations of gender variance and same-sex sexualities in the southern Philippines, I have also demonstrated the way in which visions of the local-including gay identities - have been constituted within and through a nexus of relations (cultural and material, real and imagined) extending well beyond this particular 
locale. This nexus includes the homosexual encounters of migrant laborers in Malaysia and the Middle East, as well as the fantasies of gays in the Philippines about gay marriage in the United States.

Important, too, are the ways in which the dominant versions of locality are reformulated and rearticulated in the experience and retelling of, to rephrase Anna Tsing (1996), alien encounters.13 Thus, for instance, J's description of gay marriage in the United States calls attention to the way (from his perspective) gay marriage makes possible the reformulation of marriage from a social contract that sanctions gender inequality to one that reflects an agreement between friends. $J$ thus documents his exclusion from local marriage transactions and also calls into question the social fictions that underpin the institution of marriage as the final arbiter of gendered and sexual identifications (cf. Borneman 1996). J's story may not constitute gay politics in the conventional Anglo-European sense, since local gay experience is still valorized in terms of transgendered identifications. Nevertheless, J's story remains an example of the way in which the transnational circulation of images become signs that are injected into local formulations (and critiques of) gendered sexual identifications.

Following Foucault (1990), other theorists have looked at the development of the sexual subject out of the proliferation of discourses of sexuality originating in the West (for example, Garcia 1996). In this article, I have illustrated the dynamics of gendered identifications and sexual practices that unfold between-or better, unfurl across-national boundaries and borders. The same dynamics generate divergent transactional trajectories and ethnic and national classifications: the gendered sexual categories of gay, bantut, and silahis are constituted in relation to the variously imagined worlds of conflict and desire-be they Muslim Tausug, Christian Filipino, Arab, or American. In sum, what my ethnography demonstrates is that sexuality and gender, like ethnicity, are most usefully thought about not in terms of static boundaries and isolated "it" entities (Herdt 1991). Rather, they emerge from (among other sources) the telling and retelling, mapping and remapping of forms of love and desire, as multidimensional cartographies of power and resistance through which various subjectivities create and re-create themselves.

\section{Notes}

1. A good example of anthropological work on sexuality and one that goes beyond the simple "naming and claiming" approach is Herdt's $(1987,1993)$ now classic work on the Sambia. Herdt demonstrates that same-sex relations in Melanesia are fundamentally different from the Western definition of homosexuality, both in terms of the ritual context and in terms of the wider kinship implications of semen transactions.

2. This article consolidates and draws together work I have published elsewhere (Johnson 1995a, $1995 b, 1996,1997)$. The theoretical focus of this essay has benefited from both the comments of anonymous reviewers and from recent contributions to the study of gender and sexuality in Southeast Asia, including in particular two texts that deal with the issue of same-sex sexuality in the Philippines (Garcia 1996; Manalansan IV 1995). Dealing with metropolitan areas of the Philippines, Garcia documents the way that the discourse of homosexuality originating in the West has been mapped onto and valorized the meaning of the transgendered bakla as psychosexual inverts. Manalansan on the other hand has examined the way Filipino gays who are part of diaspora communities in North America have variously negotiated and reformulated their identities. This reformulation has occurred as a response to the different expectations and understandings of samesex sexuality and the AIDs pandemic in the United States and the Philippines.

3. It is important to note at the outset the specific cultural and historical context within which the term gay is deployed here. In the southern Philippines, the term gay is as much about transgender identities as it is about same-sexual orientation. As I discuss below, same-sex sexuality is gendered in such a way that only feminine-identified individuals are classified as gay. 
4. I stress the conventional nature of the activo and passivo distinctions, for as Murray (1992) and others have suggested, such distinctions, although drawn in many parts of the world, do not in fact reflect actual sexual practices, and are oftentimes unproblematically linked to the notion of gender roles. Cornwall (1994), for instance, has explored the ways in which homosexual encounters in Brazil, variously mediated by monetary transactions, at times controvert the conventional definition of the respective masculine and feminine sexual positions of men and male transvestitehomosexuals (travestis). In speaking of the local protocols of engendered sexuality, moreover, I am following Winkler (1990), who in an insightful and imaginative account of sexuality in ancient Greece, employs the term protocol not only to indicate the symbolic framework within which sex and gender categories were constructed, but also to indicate the fact that, precisely because of the conventional or arbitrary nature of the protocols, they were always open to contravention.

5. While there is much correspondence between Whitham's (1992) and Mathews's (1990) papers and the description of gay-men relations I present here, it is important to note some important points of divergence. On the one hand, Whitham characterizes all gay-men relations in Cebu as being call-boy relations, which I think, given my own data on gay relations, glosses over much of gay representations that clearly differentiate between strictly sexually oriented relationships mediated by cash payment and other romantic interests that are negotiated through other forms of gifting arrangements. Mathews, on the other hand, writing within the context of what he calls homosexual prostitution in the Ermita red-light tourist district of Manila, is writing about a situation that is not necessarily typical of Filipino gay-men relations, and a more apt comparison may be with bantut experience in Sabah as bennie boys. Thus it is perhaps not surprising that there is a wide range of gender identities proffered by the boys, some identifying as transgender-homosexual bakla' (Tagalog for bantut), but others still retaining a male identity (which as I suggest most call boys in the Philippines do) while adopting the term gay in this context. Importantly, while Mathews describes all of these as engaging in homosexual prostitution, he does emphasize that for the bennie boys there is a continuum of intentionalities from the strictly mercenary (commercial) to the affectively inclined (regular) along which they place themselves.

6. The majority of the gays in Jolo identified themselves as Muslim Tausug, and in several cases, said they attended the major Friday prayer and service at the mosque. There are gays in Jolo, however, who identify themselves as Christians or Bisaya'. Among themselves, gays attempt to downplay ethnic d ifferences. Indeed, the Sulu Sisters' Club and the Jolo Gay Civic Association (which organizes beauty contests and talent shows for women, men, and gays) reportedly sponsored a movement for peace and reconciliation between ethnic-religious groupings in the town. Despite this movement, local gay discourse reproduces the stereotype of local Tausug men as being both extremely virile and aggressive warriors. They also recognize that they are discriminated against because they do not conform to the ideals of Tausug masculinity.

7. Bahasa Sinug or Tausug (the language of the Tausug) was the language I most commonly used in conversations and interviews with local gays. For their part, however, gays often responded in a mixture of Tausug, Tagalog (the national language of the Philippines), and English (sometimes fluent and sometimes broken, depending on the level of education they had attained). In this and other extracts from my field notes, I have used italicization to indicate direct quotations where the speaker was using English. Except where otherwise noted, unitalicized text represents free translation from Tausug.

8. Whether or not these foreign men considered themselves to be gay in the Western sense seemed largely inconsequential to gay accounts of their relationships with them. The main point was that they were perceived as masculine-identified men who were interested in feminine-identified Filipino men.

9. It is perhaps useful to recall Gell's (1992) point that "sharing" has too often been simply subsumed within the general category of "reciprocity," thus eliding the particular sentiments and moral force or ethos of such transactions. 
10. Kiefer (1972) has distinguished these two as disinterested love (lasa) and possessive love (kasi). There are several problems with these translations, not least of which is the culturally specific semantic range of self-interest and possession. I think it is much more useful to think about kasi and lasa in terms of the kinds of reciprocal sociality that each is seen to entail.

11. Figures 1 and 2 are only meant as heuristic devices, a way of visually organizing and presenting the various and partial connections that I have drawn among transactional forms, gendered identifications, and imagined worlds. Some readers have found them useful in thinking through the ethnographic detail presented in this article, and I include them for those who, like myself, find them useful conceptual tools.

12. Rafael (1987), for instance, documents the efforts of Spanish colonizers to exact Filipino submission to the crown during colonialism in Tagalog society. The Spanish colonizers tried to bring Filipino into submission by refiguring the local terms of exchange and indebtedness, making God, through the institution of the church, both the originary source and ultimate object of "debts of the inside" (utang na loob).

13. Tsing's work, although it does not focus on either transgendering or same-sex sexuality, demonstrates how three Dyak women's stories of "alien romance" subvert the dominant international vision of Asian women as docile bodies and question local standards and conventions of male privilege as explorers in search of adventure and romance.

\section{References}

Altman, Dennis 1996 Rupture or Continuity? The Internationalization of Gay Identities. Social Text 48 14(3):77-94.

Appadurai, Arjunu 1991 Global Ethnoscapes: Notes and Queries for a Transnational Anthropology. In Recapturing Anthropology: Working in the Present. Richard Fox, ed. Pp. 191-210. Santa Fe, NM: School of American Research Press.

Borneman, John 1996 Until Death Do Us Part: Marriage/Death in Anthropological Discourse. American Ethnologist 23(2):215-238.

Cannell, Fenella 1991 Catholicism, Spirit Mediums and the Ideal of Beauty in a Bicolano Community, Philippines. Ph.D. dissertation, University of London.

Cornwall, Andrea 1994 Gendered Identities and Gender Ambiguity among Travestis in Salvador, Brazil. In Dislocating Masculinity: Comparative Ethnographies. Andrea Cornwall and Nancy Lindisfarne, eds. Pp. 111 -132. London: Routledge.

Dumont, John Paul 1992 Visayan Vignettes. Chicago: University of Chicago Press.

Foucault, Michel 1990 The History of Sexuality. Robert Hurley, Trans. London: Penguin.

Garcia, J. Neil 1996 Gay Culture in the Philippines: The Last Thirty Years. Quezon City, Philippines: University of the Philippines Press.

Gell, Alfred 1992 Inter-Tribal Commodity Barter and Reproductive Gift-Exchange in Old Melanesia. In Barter, Exchange, and Value: An Anthropological Approach. Caroline Humphrey and Stephen HughJones, eds. Pp. 142-168. Cambridge: Cambridge University Press.

Greenberg, Douglas F. 1988 The Construction of Homosexuality. Chicago: University of Chicago Press. 
Herdt, Gilbert 1987 The Sambia: Ritual and Gender in New Guinea. New York: Holt, Rinehart and Winston.

1991 Representations of Homosexuality: An Essay on Cultural Ontology and Historical Comparison, Part I. Journal of the History of Sexuality 1: 481-504.

1993 Semen Transactions in Sambia Culture. In Ritualized Homosexuality in Melanesia. 2nd edition. Gilbert Herdt, ed. Pp. 167-210. Berkeley: University of California Press.

Hollensteiner, Mary R. 1972 Reciprocity in the Lowland Philippines. In Four Readings on Philippine Values. F. Lynch and Alfonso de Guzman II, eds. Pp. 65-88. Quezon City, Philippines: Ateneo de Manila.

Johnson, Mark 1995a Transgender Men and Homosexuality in the Southern Philippines: Ethnicity, Political Violence and the Protocols of Engendered Sexualities amongst the Muslim Tausug and Sama. South East Asia Research 3(1):46-66.

1995b Remembrances, Identity, Cultural Transformation and Transgendering in the Southern Philippines. International Journal of Comparative Race and Ethnic Studies 2(1):116-132.

1996 Negotiating Style and Mediating Beauty. Transvestite (Gay-Bantut) Beauty Contests in the Southern Philippines. In Beauty Queens on the Global Stage: Gender, Contests, and Power. Colleen Cohen, Richard Wilk, and Beverly Steoltje, eds. Pp. 89-104. London: Routledge.

1997 Beauty and Power: Transgendering and Cultural Transformation in the Southern Philippines. Oxford and New York: Berg.

Kiefer, Thomas 1972 The Tausug: Violence and Law in Philippine Moslem Society. New York: Holt, Rinehart and Winston. Leach, Edmund R. 1971 Rethinking Anthropology. London: Athlone Press.

Manalansan IV, Martin F. 1995 Speaking of Aids: Language and the Filipino "Gay" Experience in America. In Discrepant Histories: Translocal Essays on Filipino Cultures. Vicente L. Rafael, ed. Pp. 193-220. Manila, Philippines: Anvil Publishing.

Mathews, Paul W. 1990 Male Prostitution in Manila. Philippine Sociological Review 38:55-74. Murray, Stephen. O., ed. 1992 Oceanic Homosexualities. London: Garland Publishing.

Rafeal, Vincente L. 1988 Contracting Colonialism: Translation and Christian Conversion in Tagalog Society under Early Spanish Rule. Ithaca, NY: Cornell University Press.

Rapport, Nigel, and Andrew Dawson, eds. 1998 Migrants of Identity: Perceptions of Home in a World of Movement. Oxford: Berg Publishers.

Thomas, Nicholas 1991 Entangled Objects: Exchange, Material Culture and Colonialism in the Pacific. London: Harvard University Press.

Tsing, Anna L. 1996 Alien Romance. In Fantasizing the Feminine in Indonesia. Laurie j. Sears, ed. Pp. 295-317. Durham, NC: Duke University Press. 
Weston, Kath 1993 Lesbian/Gay Studies in the House of Anthropology. Annual Review of Anthropology 22:339-367.

Whitham, Fredrick L. 1992 Bayot and Callboy: Homosexual-heterosexual Relations in the Philippines. In Oceanic Homosexualities S. Murray, ed. Pp. 231-248. London: Garland Publishing.

Winkler, John J. 1990 The Constraints of Desire: The Anthropology of Sex and Gender in Ancient Greece. London: Routledge 